\title{
Responses of photosynthetic characteristics and growth in rice and winter wheat to different elevated $\mathrm{CO}_{2}$ concentrations
}

\author{
C. LIU*, Z.H. HU*,+, L.F. YU ${ }^{* *}$, S.T. CHEN ${ }^{*}$, and X.M. LIU** \\ Collaborative Innovation Center on Forecast and Evaluation of Meteorological Disasters, School of Applied \\ Meteorology, Nanjing University of Information Science \& Technology, 210044 Nanjing, China ${ }^{*}$ \\ State Key Laboratory of Vegetation and Environmental Change, Institute of Botany, Chinese Academy of Sciences, \\ 100093 Beijing, China ${ }^{* *}$
}

\begin{abstract}
This study investigated the effects of different elevated $\mathrm{CO}_{2}$ concentrations [ambient $\mathrm{CO}_{2}$ concentration $(\mathrm{CK})$, $\mathrm{CK}$ plus $40 \mu \mathrm{mol} \mathrm{mol}{ }^{-1}\left(\mathrm{~T}_{1}\right), \mathrm{CK}$ plus $\left.200 \mu \mathrm{mol} \mathrm{mol}^{-1}\left(\mathrm{~T}_{2}\right)\right]$ on photosynthetic characteristics and growth of rice (Oryza sativa $\mathrm{L}$.) and winter wheat (Triticum aestivum $\mathrm{L}$.). The results showed that $\mathrm{T}_{2}$ treatment decreased the net photosynthetic rate and leaf nitrogen content (LNC) but increased the light-saturated net photosynthetic rate of rice. Additionally, $\mathrm{T}_{2}$ treatment increased biomass accumulation and yield in both rice and winter wheat to some extent. $T_{1}$ treatment, however, had little effect on photosynthetic parameters, LNC, biomass, and yield during the rice and winter wheat growing seasons. The above results suggest that the photosynthesis and growth responses of rice and winter wheat to different $\mathrm{CO}_{2}$ concentrations differed, in general, the increase of $\mathrm{CO}_{2}$ concentrations influenced more photosynthetic performance and growth of $\mathrm{C}_{3}$ plants than lower $\mathrm{CO}_{2}$ concentrations.
\end{abstract}

Keywords: climate change; crop; gas exchange; open-top chamber; photosynthetic acclimation.

\section{Introduction}

Elevated carbon dioxide $\left(\mathrm{eCO}_{2}\right)$ concentrations, mainly due to the burning of fossil fuels and human land-use activities, have been shown to have a profound impact on global climate change (Tausz-Posch et al. 2020). The atmospheric $\mathrm{CO}_{2}$ concentration has risen from a preindustrial level of approximately $280 \mu \mathrm{mol} \mathrm{mol} \mathrm{m}^{-1}$ to the current level of $410 \mu \mathrm{mol} \mathrm{mol}^{-1}$ (Shabbir et al. 2019), and it is expected to reach $700 \mu \mathrm{mol} \mathrm{mol}{ }^{-1}$ by the end of the $21^{\text {st }}$ century (Srinivasarao et al. 2016). As a necessary substrate for photosynthesis, the changing $\mathrm{CO}_{2}$ concentrations directly or indirectly affect the morphological and physiological characteristics of plants and then affect agricultural and natural ecosystems (Tausz et al. 2013).

Rice (Oryza sativa L.) and wheat (Triticum aestivum L.) are the most important food crops in Asia, providing food grains for more than $20 \%$ of the population worldwide (Guo et al. 2016). With the growth of world population, global food demand is estimated to increase by $100-110 \%$ from 2005 to 2050 (Tilman et al. 2011). However, the rising atmospheric $\mathrm{CO}_{2}$ concentrations are coincident with the increase in temperature, altered precipitation, and intense extreme events, which may have opposite effects on sustainable food production (Bencke-Malato et al. 2019). Therefore, it is a challenge to improve crop productivity to meet the growing human food demand on the background of global climate change (Saha et al. 2015). With the rising atmospheric $\mathrm{CO}_{2}$ concentrations, many scholars pay extensive attention to the ' $\mathrm{CO}_{2}$ fertilization effect', that is, the promotion of plant growth or productivity by the increase of atmospheric $\mathrm{CO}_{2}$ concentrations, in the hope that it will compensate for the crop yield reduction caused by climate change to a certain extent (Lv et al. 2020).

Over the last three decades, the simulation of plant growth responses to $\mathrm{eCO}_{2}$ concentrations has been conducted using growth chambers, closed-top chambers, open-top chambers (OTC), and free air carbon dioxide enrichment (FACE) experiment (Uprety et al. 2006, Reddy et al. 2010, Dusenge et al. 2019). Numerous studies have

\footnotetext{
Received 22 June 2020, accepted 22 September 2020.

${ }^{+}$Corresponding author; e-mail: zhhu@nuist.edu.cn

Abbreviations: AQY - apparent quantum yield; $C_{\mathrm{a}}$ - atmospheric $\mathrm{CO}_{2}$ concentration; $\mathrm{CE}$ - carboxylation efficiency; $C_{\mathrm{i}}-$ intercellular $\mathrm{CO}_{2}$ concentration; $C_{\mathrm{i}} / C_{\mathrm{a}}$ - the ratio of intercellular $\mathrm{CO}_{2}$ concentration to ambient $\mathrm{CO}_{2} ; \mathrm{eCO}_{2}$ - elevated carbon dioxide; $g_{\mathrm{s}}-$ stomatal conductance; LNC - leaf nitrogen content; $P_{\mathrm{g}}$ - gross photosynthetic rate; $P_{\mathrm{N}}$ - net photosynthetic rate; $P_{\mathrm{Nmax}}-$ light-saturated net photosynthetic rate; PNUE - photosynthetic nitrogen-use efficiency; $R_{\mathrm{D}}$ - dark-respiration rate; $R_{\mathrm{P}}-$ photorespiration rate; TGM - thousand-grain mass.

Acknowledgments: This work was supported by grants from the National Natural Science Foundation of China $(41775152,41530533)$, the National Key Research and Development Program of China (2019YFD1002202), the Postgraduate Research \& Practice Innovation Program of Jiangsu Province (SJKY19_0948). Thanks to Tianhang Create Technology Co., Ltd. for the design and maintenance of the experimental control system. We are also grateful to Professor Y. Huang, W.J. Sun, C.X. Zhang, Y. Xia, P.P. Fan, X. Deng, X.Y. Hu, and L.J. Yu for their considerable help with the field experiments.
} 
shown that the rising $\mathrm{CO}_{2}$ concentrations could stimulate the net photosynthetic rate (Nowak et al. 2004, Ainsworth and Rogers 2007) and increase dry matter production and yield, particularly in $\mathrm{C}_{3}$ plants (Liu et al. 2008, Bishop et al. 2014). Besides, $\mathrm{CO}_{2}$ enrichment could induce partial stomatal closure, increase stomatal resistance, decrease stomatal conductance, and improve water-use efficiency (Leakey et al. 2009, Kimball 2016, Pan et al. 2020).

After long-term exposure to high $\mathrm{eCO}_{2}$ concentrations, however, the initial stimulation on photosynthetic rate will not increase continuously, and sometimes it will be lower than that in plants grown under ambient conditions (Seneweera 2011, Warren et al. 2015, Pastore et al. 2019). This phenomenon is commonly called photosynthetic acclimation or downregulation and has been extensively reported in the literature (Yong et al. 2007, Alonso et al. 2009, Salazar-Parra et al. 2015). Furthermore, as $\mathrm{CO}_{2}$ concentrations increase, these positive $\mathrm{eCO}_{2}$ concentrations effects are often accompanied by the changed nutrient contents in plant tissues, such as the decrease of tissue nitrogen $(\mathrm{N})$ concentration (Seneweera et al. 2002, Dier et al. 2019). The leaf nitrogen content (LNC) is one of the key factors that determine photosynthetic capacity and photosynthetic nitrogen-use efficiency (PNUE) (Moon et al. 2015). The $\mathrm{CO}_{2}$ enrichment has been reported to promote the accumulation of photoassimilates and therefore dilute plant tissue nitrogen content such that LNC is decreased (Gifford et al. 2000). Ainsworth and Long (2005) examined the literature on the effects of $\mathrm{eCO}_{2}$ concentrations on LNC of plants using meta-analysis and showed that $\mathrm{CO}_{2}$ enrichment decreased LNC by an average of $13 \%$ under FACE experiments.

To our knowledge, most of the previous studies on this subject have focused on the effects of high $\mathrm{eCO}_{2}$ concentrations (i.e., a doubled $\mathrm{CO}_{2}$ concentration or elevated by $200 \mu \mathrm{mol} \mathrm{mol}{ }^{-1}$ more than the ambient level) on growth, development, and yield of plants (Kim et al. 2003, Singh et al. 2017). The increase of atmospheric $\mathrm{CO}_{2}$ concentration is a gradual process and will not increase to a very high concentration in a short period of time. Even if atmospheric $\mathrm{CO}_{2}$ concentrations had increased at a rate of $2.11 \mu \mathrm{mol} \mathrm{mol}{ }^{-1}$ year $^{-1}$ over the last decade (IPCC 2014), it would take approximately 100 years to result in an elevation of $200 \mu \mathrm{mol} \mathrm{mol} \mathrm{m}^{-1}$ over the ambient concentration. To the best of our knowledge, little is studied about how the photosynthetic characteristics and growth of plant response to low $\mathrm{eCO}_{2}$ concentrations.

In this study, an in situ field experiment in which rice (Oryza sativa L.) and winter wheat (Triticum aestivum L.) was exposed to three different concentrations of $\mathrm{CO}_{2}$ (ambient, ambient $+40 \mu \mathrm{mol} \mathrm{mol}{ }^{-1}$, and ambient + $200 \mu \mathrm{mol} \mathrm{mol}^{-1}$ ) was performed using OTC from 2016 to 2017. The objectives of this study were to determine the potential effects of different $\mathrm{eCO}_{2}$ concentrations on the photosynthetic performance, biomass accumulation, and yield of rice and winter wheat, under the hypothesis that high $\mathrm{eCO}_{2}$ concentrations could induce a stress response in vegetation that could result in a high sensitivity to changes of these growth parameters, while low $\mathrm{eCO}_{2}$ concentrations are closer to the ambient levels and plants might be insensitive to them.

\section{Materials and methods}

Site description: The field experiment was conducted at the Agricultural Meteorology and Ecology Experimental Station of Nanjing University of Information Science and Technology $\left(32^{\circ} 16^{\prime} \mathrm{N}, 118^{\circ} 86^{\prime} \mathrm{E}\right)$ in eastern China from 2016 to 2017 . This site belongs to the subtropical humid climate. The average annual precipitation and temperature are approximately $1,100 \mathrm{~mm}$ and $15.6^{\circ} \mathrm{C}$, respectively. The total annual sunshine time exceeds $1,900 \mathrm{~h}$, and the frostless period is more than $237 \mathrm{~d}$. Rice (Oryza sativa L. 'Nanjing 9108') and winter wheat (Triticum aestivum L. 'Yangmai 22') rotation system prevails in this region, and the soil (0-20 cm depth) is classified as yellow-brown soil (26.1\% clay) with an organic $\mathrm{C}$ of $11.95 \mathrm{~g} \mathrm{~kg}^{-1}$, total $\mathrm{N}$ of $1.45 \mathrm{~g} \mathrm{~kg}^{-1}$, and $\mathrm{pH} 6.3$ (1:2, soil:water suspension).

Experimental design: The field experiment consisted of three treatments: ambient $\mathrm{CO}_{2}$ concentration (CK),

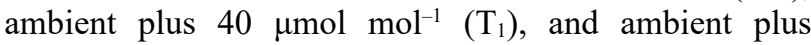
$200 \mu \mathrm{mol} \mathrm{mol}{ }^{-1}\left(\mathrm{~T}_{2}\right)$. Each treatment was replicated four times. In total, the field experiment contained 12 independent OTC, which were arranged in the field at equal spacing.

Locally prevalent Japonica rice cultivar (Nanjing 9108) was sown under ambient field conditions on May 20 in 2016 and transplanted (30-d old) manually into each OTC, with three seedlings per hill and 30 hills per square meter. Fertilizer was applied at a rate of $176 \mathrm{~kg}(\mathrm{~N}) \mathrm{ha}^{-1}$ in three split doses during the rice growing season. The percentage of nitrogen fertilizer applied was at the ratio of transplant (basal fertilizer): tillering: heading $=40: 30: 30 \%$. The basal fertilizer was compound fertilizer $\left(\mathrm{N}: \mathrm{P}_{2} \mathrm{O}_{5}: \mathrm{K}_{2} \mathrm{O}=\right.$ $15: 15: 15 \%$ ), the tillering and heading stages fertilizer was urea (nitrogen content $46.7 \%$ ). Winter wheat cultivar (Yangmai 22) was hand sown with a density of 320 kernels per square meter on 15 November in 2016. Fertilizer was applied at a rate of $220 \mathrm{~kg}(\mathrm{~N}) \mathrm{ha}^{-1}$ in two split doses during the winter wheat growing season. The ratio of the nitrogen fertilizer applied was seeding (basal fertilizer): turning green $=70: 30 \%$. Other crop management measures were conducted according to local practices. The detailed information related to the main growth stages and fertilization schedules is shown in the text table below.

OTC facilities: The field experiment was conducted using OTC, each of which was a regular octagonal prism constructed using an aluminum alloy frame $\left(12 \mathrm{~m}^{2}\right.$ bottom area and $3 \mathrm{~m}$ in height) with a highly transparent glass covering ( $3 \mathrm{~mm}$ thickness and $90 \%$ light transmittance). The vertical beams of the frame were bent inward with a length of $0.9 \mathrm{~m}$ and a $45^{\circ}$ tilt. The top of each OTC had a tapered opening to facilitate top air exchange and kept the temperature and humidity inside of the chambers closer to the natural environment. Each OTC was equipped with a $\mathrm{CO}_{2}$ sensor (GMM222, Vaisala Inc., Helsinki, Finland) with 


\begin{tabular}{llll}
\hline Date & Rice & Date & Winter wheat \\
\hline 20 May 2016 & Seeding & 15 November 2016 & Seeding, \\
& Transplanting, & $15.4 \mathrm{~g}(\mathrm{~N}) \mathrm{m}^{-2}, 15.4 \mathrm{~g}(\mathrm{P}) \mathrm{m}^{-2}, 15.4 \mathrm{~g}(\mathrm{~K}) \mathrm{m}^{-2}$ \\
21 June 2016 & $\begin{array}{l}\text { 1 December 2016 } \\
\text { 7.04 } \mathrm{g}(\mathrm{N}) \mathrm{m}^{-2}, 7.04 \mathrm{~g}(\mathrm{P}) \mathrm{m}^{-2}, 7.04 \mathrm{~g}(\mathrm{~K}) \mathrm{m}^{-2}\end{array}$ & Seedling \\
5 July 2016 & Tillering, & 6 February 2017 & Turning green, \\
& $5.28 \mathrm{~g}(\mathrm{~N}) \mathrm{m}^{-2}$ & & $6.6 \mathrm{~g}(\mathrm{~N}) \mathrm{m}^{-2}$ \\
18 July 2016 & Jointing & 7 March 2017 & Jointing \\
28 August 2016 & $\begin{array}{l}\text { Heading, } \\
\text { 9 November 2016 } 28 \mathrm{~g}(\mathrm{~N}) \mathrm{m}^{-2}\end{array}$ & 1 April 2017 & Heading \\
\hline
\end{tabular}

a range of $0-2,000 \mu \mathrm{mol} \mathrm{mol}{ }^{-1}$ to detect $\mathrm{CO}_{2}$ concentrations in real time. Circular polyvinyl chloride tubes $(15 \mathrm{~mm}$ in diameter) with small holes ( $2 \mathrm{~mm}$ in diameter) were fixed around the $T_{1}$ and $T_{2}$ treatments wall approximately $1.4 \mathrm{~m}$ above the ground. Using the $\mathrm{CO}_{2}$ cylinder as the air source (high-pressure liquid $\mathrm{CO}_{2}$ with a purity of $99 \%$ ), the $\mathrm{CO}_{2}$ gas vaporized by the heater was sprayed into the $T_{1}$ and $\mathrm{T}_{2}$ treatments through the blower. Solenoid valves linked a computer programmed automatic $\mathrm{CO}_{2}$ concentration control system. When the $\mathrm{CO}_{2}$ concentration of the $\mathrm{T}_{1}$ and $\mathrm{T}_{2}$ treatments was lower than the target concentration, the solenoid valves would open for supplementing $\mathrm{CO}_{2}$. The automatic control system operated for $24 \mathrm{~h}$ per day and adjusted the supply of $\mathrm{CO}_{2}$ gas every two seconds to maintain the target $\mathrm{CO}_{2}$ concentration of the $\mathrm{T}_{1}$ and $\mathrm{T}_{2}$ treatments. Additionally, each OTC had two fans installed inside to evenly mix the internal gases.

During the rice growing season, the $\mathrm{CO}_{2}$ exposure treatments were performed from 21 June to 9 November in 2016. The average $\mathrm{CO}_{2}$ concentrations in the $\mathrm{CK}, \mathrm{T}_{1}$, and $\mathrm{T}_{2}$ treatments were $413 \pm 13,439 \pm 16$, and $596 \pm 35$ $\mu \mathrm{mol} \mathrm{mol}{ }^{-1}$, respectively. During the winter wheat growing season, the $\mathrm{CO}_{2}$ fumigation was initiated from 20 February to 12 May in 2017, and the average $\mathrm{CO}_{2}$ concentrations of the $\mathrm{CK}, \mathrm{T}_{1}$, and $\mathrm{T}_{2}$ treatments were $412 \pm 8,447 \pm 13$, and $602 \pm 30 \mu \mathrm{mol} \mathrm{mol}{ }^{-1}$, respectively.

Gas exchange: Light-response curve was measured using a $\mathrm{Li}-6400$ portable photosynthesis system ( $\mathrm{Li}$-Cor Inc., Lincoln, NE, USA) during the main growth stages of the rice and winter wheat. The fully expanded, healthy, functional leaf was selected for the gas-exchange measurement under the sunny and cloudless conditions. PAR was sequentially set to 2,$000 ; 1,500 ; 1,000 ; 800$, $600,400,200,100,50,20,0 \mu \mathrm{mol}$ (photon) $\mathrm{m}^{-2} \mathrm{~s}^{-1}$ with a red-blue LED light source. The leaf temperature was set according to the plant growth environment temperature, and the relative humidity was controlled at $60 \%$. Gasexchange properties were logged after the photosynthesis system parameters achieved stability. Gas-exchange parameters were calculated according to Thornley (1976): where $P_{\mathrm{N}}$ is net photosynthetic rate $\left[\mu \mathrm{mol}\left(\mathrm{CO}_{2}\right) \mathrm{m}^{-2} \mathrm{~s}^{-1}\right]$, PAR is photosynthetically active radiation $[\mu \mathrm{mol}($ photon) $\mathrm{m}^{-2} \mathrm{~s}^{-1}$, AQY is apparent quantum yield $\left[\mu \mathrm{mol}\left(\mathrm{CO}_{2}\right)\right.$ $\left.\mathrm{m}^{-2} \mathrm{~s}^{-1}\right], P_{\mathrm{Nmax}}$ is light-saturated net photosynthetic rate $\left[\mu \mathrm{mol}\left(\mathrm{CO}_{2}\right) \mathrm{m}^{-2} \mathrm{~s}^{-1}\right], R_{\mathrm{D}}$ is dark respiration $\left[\mu \mathrm{mol}\left(\mathrm{CO}_{2}\right)\right.$ $\mathrm{m}^{-2} \mathrm{~s}^{-1}$, and $\theta$ is curvature of light-response curve (dimensionless).

The $\mathrm{CO}_{2}$-response curves were determined after lightresponse curve measurement, and $P_{\mathrm{N}}$ was measured at $13 \mathrm{CO}_{2}$ concentrations $(400,300,200,100,50,20,400$, 600,$\left.800 ; 1,000 ; 1,200 ; 1,500 ; 2,000 \mu \mathrm{mol} \mathrm{mol} \mathrm{m}^{-1}\right)$. The saturating light was set at 1,200 $\mu$ mol(photon) $\mathrm{m}^{-2} \mathrm{~s}^{-1}$. The $\mathrm{CO}_{2}$-injection system maintained constant $\mathrm{CO}_{2}$ concentrations in the sample chamber. The $\mathrm{CO}_{2}$-response parameters were calculated according to the method proposed by Watling et al. (2000). The formula is as follows: $A=a\left(1-e^{-b x}\right)+c$. Where $A$ is the net photosynthetic rate $\left(P_{\mathrm{N}}\right)\left[\mu \mathrm{mol}\left(\mathrm{CO}_{2}\right) \mathrm{m}^{-2} \mathrm{~s}^{-1}\right], a$ is $\mathrm{CO}_{2}$-saturated net photosynthetic rate $\left[\mu \mathrm{mol}\left(\mathrm{CO}_{2}\right) \mathrm{m}^{-2} \mathrm{~s}^{-1}\right], b$ is carboxylation rate, $x$ is intercellular $\mathrm{CO}_{2}$ concentration $\left(C_{\mathrm{i}}\right)\left[\mu \operatorname{mol}\left(\mathrm{CO}_{2}\right)\right.$ $\left.\mathrm{mol}^{-1}\right]$, and $c$ is photorespiration rate $\left(R_{\mathrm{P}}\right),\left[\mu \mathrm{mol}\left(\mathrm{CO}_{2}\right)\right.$ $\mathrm{m}^{-2} \mathrm{~s}^{-1}$. Using this equation, the carboxylation efficiency (CE) was calculated as $b(a+c)$.

LNC: After measuring the photosynthesis, the leaf was removed and placed in an oven at $105^{\circ} \mathrm{C}$ for $30 \mathrm{~min}$ and then dried at $65^{\circ} \mathrm{C}$ for $48 \mathrm{~h}$. The LNC was measured using a CHNOS Elemental Analyzer (Vario EL III, Elementar Analysensystem GmBH, Hanau, Germany).

Biomass and yield: The rice and winter wheat were harvested at the jointing and heading stages. Samples were divided into root, stem, leaf, and ear; all parts were dried in an oven at $65^{\circ} \mathrm{C}$ for $48 \mathrm{~h}$ and weighed. After the crop matured, the $1 \mathrm{~m}^{2}$ crop samples of each OTC were harvested for yield analysis.

Statistical analysis: All statistical analyses were performed by one-way analysis of variance (ANOVA) using SPSS 21.0 software (SPSS Inc., Chicago, IL, USA), and comparisons between the mean values were accomplished by the least

$P_{\mathrm{N}}=\frac{\mathrm{PAR} \times \mathrm{AQY}+P_{\mathrm{Nmax}}-\sqrt{\left(\mathrm{PAR} \times \mathrm{AQY}+P_{\mathrm{Nmax}}\right)^{2}}-4 \theta \mathrm{PAR} \times \mathrm{AQY} \times P_{\mathrm{Nmax}}}{2 \theta}-R_{\mathrm{D}}$ 
significant difference $(L S D)$ at $p<0.05$. Linear regression analysis was performed on the relationship between the $P_{\mathrm{g}}$ and the LNC. All graphs were created using Origin 8.0 software (Origin Lab, Northampton, MA, USA).

\section{Results}

Photosynthetic parameters: As shown in Fig. $1 A$, at the jointing, heading, and milky maturity stages of rice, compared with the $\mathrm{CK}$ and $\mathrm{T}_{1}$ treatments, the $P_{\mathrm{N}}$ of the $\mathrm{T}_{2}$ treatment significantly decreased by 10 and $8 \%, 20$ and $14 \%$, and 18 and $18 \%$, respectively. During the winter wheat growing season, the $\mathrm{T}_{2}$ treatments had no significant effect on $P_{\mathrm{N}}$ at the two different stages (Fig. $1 B$ ). The $\mathrm{T}_{1}$ treatment, however, had no significant effect on $P_{\mathrm{N}}$ in both rice and winter wheat. In general, the $\mathrm{CO}_{2}$ concentration did not have a significant effect on the $g_{\mathrm{s}}, C_{\mathrm{i}}$, and $C_{\mathrm{i}} / C_{\mathrm{a}}$ in any of the growth stages during the rice (Fig. $1 C, E, G)$ and winter wheat growing seasons (Fig. $1 D, F, H$ ).
The light and $\mathrm{CO}_{2}$-response parameters are shown in Table 1. Compared with the $\mathrm{CK}$ and $\mathrm{T}_{1}$ treatments, the $P_{\mathrm{Nmax}}$ of the $\mathrm{T}_{2}$ treatment significantly increased by 43 and $42 \%$, and 41 and $39 \%$, at the jointing and heading of rice, respectively. Meanwhile, no significant difference in any other index (AQY, $R_{\mathrm{D}}$, and $R_{\mathrm{P}}$ ) was found between the different treatments. During the winter wheat growing season, the $\mathrm{T}_{1}$ and $\mathrm{T}_{2}$ treatments did not significantly influence $P_{\mathrm{Nmax}}, \mathrm{AQY}, R_{\mathrm{D}}, \mathrm{CE}$, and $R_{\mathrm{P}}$. Besides, the $\mathrm{T}_{1}$ treatment had no significant effect on photosynthetic response parameters in both rice and winter wheat.

Leaf nitrogen content: During the rice growing season, compared with the CK treatment, the $T_{2}$ treatment significantly decreased the LNC by $8 \%$ at the jointing stage and $9 \%$ at the heading stage, and no significant difference was observed at the milky maturity stage. The $T_{1}$ treatment, however, had no significant effect on LNC compared with the CK treatment in any of the three different stages of

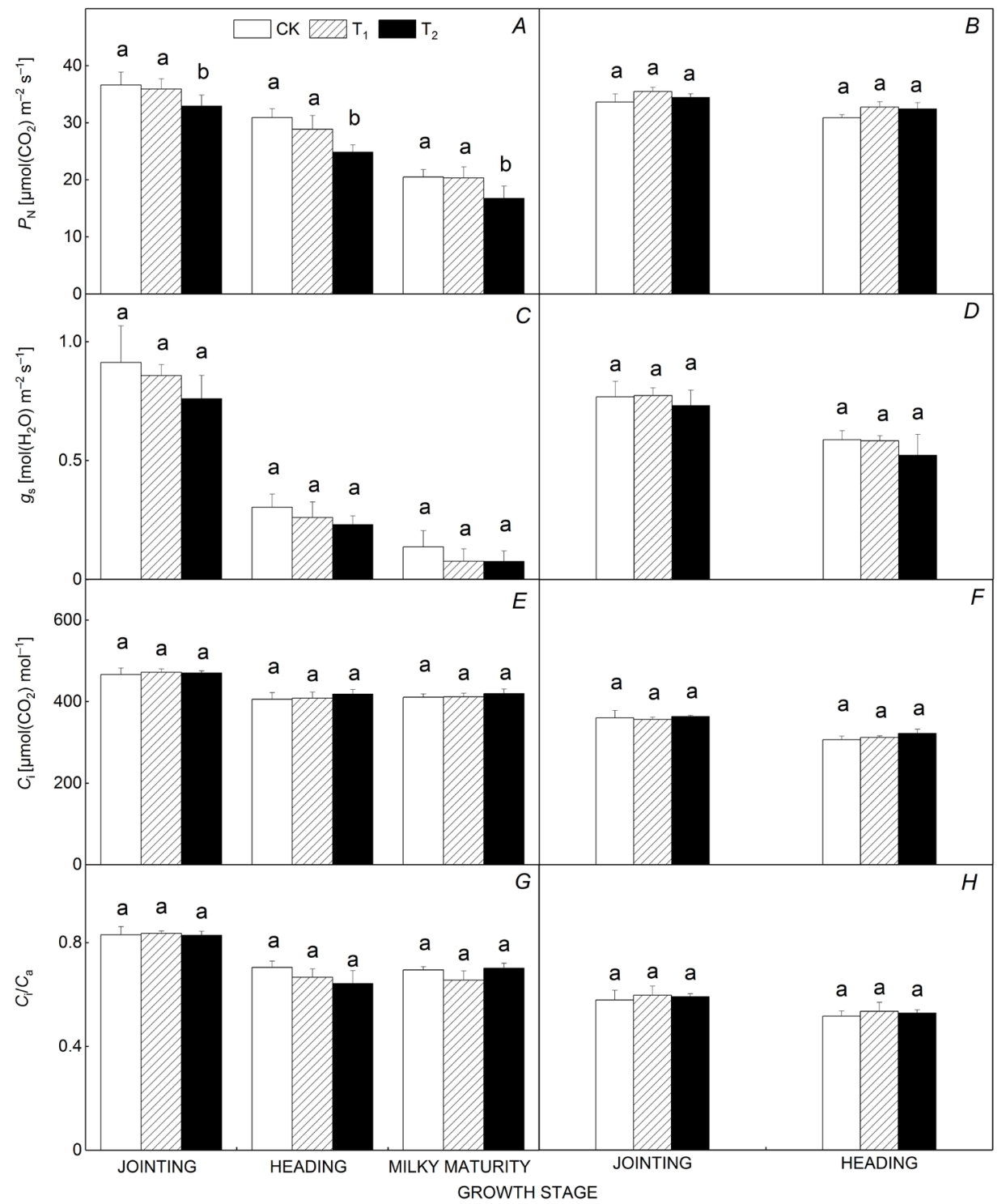

Fig. 1. Effects of different elevated carbon dioxide $\left(\mathrm{eCO}_{2}\right)$ concentrations on the net photosynthetic rate $\left(P_{\mathrm{N}}\right)$, stomatal conductance $\left(g_{\mathrm{s}}\right)$, intercellular $\mathrm{CO}_{2}$ concentration $\left(C_{\mathrm{i}}\right)$, and the ratio of intercellular $\mathrm{CO}_{2}$ concentration to ambient $\mathrm{CO}_{2}$ $\left(C_{\mathrm{i}} / C_{\mathrm{a}}\right)$ of rice $(A, C, E, G)$ and winter wheat $(B, D, F, H)$ under the same $\mathrm{CO}_{2}$ concentration $\left[\begin{array}{lll}600 \mu \mathrm{mol}\left(\mathrm{CO}_{2}\right) & \mathrm{mol}^{-1}\end{array}\right]$. CK ambient $\mathrm{CO}_{2}$ concentration; $\mathrm{T}_{1}-$ ambient plus $40 \mu \mathrm{mol} \mathrm{mol}^{-1} ; \mathrm{T}_{2}$ ambient plus $200 \mu \mathrm{mol} \mathrm{mol}^{-1}$. Data are the mean values $\pm \mathrm{SE}$ $(n=4)$. Different lowercase letters indicate a significant difference between different treatments at $p<0.05$. 
Table 1. Effects of different elevated carbon dioxide $\left(\mathrm{eCO}_{2}\right)$ concentrations on light and $\mathrm{CO}_{2}$-response parameters of rice and winter wheat. $P_{\mathrm{Nmax}}-$ light-saturated net photosynthetic rate; AQY - apparent quantum yield; CE - carboxylation efficiency; $R_{\mathrm{D}}-$ darkrespiration rate; $R_{\mathrm{P}}$ - photorespiration rate. $\mathrm{CK}$ - ambient $\mathrm{CO}_{2}$ concentration; $\mathrm{T}_{1}-$ ambient plus $40 \mu \mathrm{mol} \mathrm{mol}^{-1} ; \mathrm{T}_{2}-$ ambient plus $200 \mu \mathrm{mol} \mathrm{mol}{ }^{-1}$. Data are the mean values $\pm \mathrm{SE}(n=4)$. Different lowercase letters indicate a significant difference between different treatments at $p<0.05$.

\begin{tabular}{llllll}
\hline Parameter & Treatment & $\begin{array}{l}\text { Rice } \\
\text { Jointing }\end{array}$ & Heading & Milky maturity & $\begin{array}{l}\text { Winter wheat } \\
\text { Jointing }\end{array}$ \\
\hline$P_{\mathrm{Nmax}}\left[\mu \mathrm{mol}\left(\mathrm{CO}_{2}\right) \mathrm{m}^{-2} \mathrm{~s}^{-1}\right]$ & $\mathrm{CK}$ & $35.6 \pm 2.3^{\mathrm{b}}$ & $28.6 \pm 2.6^{\mathrm{b}}$ & $20.4 \pm 2.4^{\mathrm{a}}$ & $40.48 \pm 2.73^{\mathrm{a}}$ \\
& $\mathrm{T}_{1}$ & $36.0 \pm 2.5^{\mathrm{b}}$ & $28.9 \pm 2.1^{\mathrm{b}}$ & $25.5 \pm 3.0^{\mathrm{a}}$ & $44.65 \pm 3.42^{\mathrm{a}}$ \\
& $\mathrm{T}_{2}$ & $51.0 \pm 1.5^{\mathrm{a}}$ & $40.2 \pm 2.9^{\mathrm{a}}$ & $22.4 \pm 3.1^{\mathrm{a}}$ & $48.00 \pm 3.81^{\mathrm{a}}$ \\
$\mathrm{AQY}\left[\mu \mathrm{mol}\left(\mathrm{CO}_{2}\right) \mathrm{m}^{-2} \mathrm{~s}^{-1}\right]$ & $\mathrm{CK}$ & $0.058 \pm 0.003^{\mathrm{a}}$ & $0.043 \pm 0.007^{\mathrm{a}}$ & $0.056 \pm 0.004^{\mathrm{a}}$ & $0.067 \pm 0.002^{\mathrm{a}}$ \\
& $\mathrm{T}_{1}$ & $0.062 \pm 0.002^{\mathrm{a}}$ & $0.047 \pm 0.005^{\mathrm{a}}$ & $0.068 \pm 0.011^{\mathrm{a}}$ & $0.068 \pm 0.002^{\mathrm{a}}$ \\
& $\mathrm{T}_{2}$ & $0.062 \pm 0.006^{\mathrm{a}}$ & $0.058 \pm 0.010^{\mathrm{a}}$ & $0.061 \pm 0.002^{\mathrm{a}}$ & $0.071 \pm 0.004^{\mathrm{a}}$ \\
$R_{\mathrm{D}}\left[\mu \mathrm{mol}\left(\mathrm{CO}_{2}\right) \mathrm{m}^{-2} \mathrm{~s}^{-1}\right]$ & $\mathrm{CK}$ & $2.57 \pm 0.06^{\mathrm{a}}$ & $1.34 \pm 0.23^{\mathrm{a}}$ & $0.93 \pm 0.41^{\mathrm{a}}$ & $2.25 \pm 0.89^{\mathrm{a}}$ \\
& $\mathrm{T}_{1}$ & $2.36 \pm 0.16^{\mathrm{a}}$ & $1.49 \pm 0.27^{\mathrm{a}}$ & $0.88 \pm 0.11^{\mathrm{a}}$ & $1.20 \pm 0.17^{\mathrm{a}}$ \\
& $\mathrm{T}_{2}$ & $2.41 \pm 0.13^{\mathrm{a}}$ & $1.70 \pm 0.35^{\mathrm{a}}$ & $0.44 \pm 0.11^{\mathrm{a}}$ & $3.52 \pm 0.94^{\mathrm{a}}$ \\
& $\mathrm{CK}$ & $0.195 \pm 0.026^{\mathrm{a}}$ & $0.167 \pm 0.009^{\mathrm{a}}$ & $0.099 \pm 0.015^{\mathrm{ab}}$ & $0.207 \pm 0.021^{\mathrm{a}}$ \\
& $\mathrm{T}_{1}$ & $0.161 \pm 0.007^{\mathrm{a}}$ & $0.157 \pm 0.018^{\mathrm{a}}$ & $0.127 \pm 0.012^{\mathrm{a}}$ & $0.204 \pm 0.005^{\mathrm{a}}$ \\
& $\mathrm{T}_{2}$ & $0.142 \pm 0.012^{\mathrm{a}}$ & $0.129 \pm 0.018^{\mathrm{a}}$ & $0.090 \pm 0.007^{\mathrm{b}}$ & $0.209 \pm 0.003^{\mathrm{a}}$ \\
$R_{\mathrm{P}}\left[\mu \mathrm{mol}\left(\mathrm{CO}_{2}\right) \mathrm{m}^{-2} \mathrm{~s}^{-1}\right]$ & $\mathrm{CK}$ & $15.4 \pm 1.9^{\mathrm{a}}$ & $13.4 \pm 1.1^{\mathrm{a}}$ & $7.7 \pm 1.7^{\mathrm{a}}$ & $12.58 \pm 2.59^{\mathrm{a}}$ \\
& $\mathrm{T}_{1}$ & $12.6 \pm 0.2^{\mathrm{a}}$ & $12.6 \pm 2.0^{\mathrm{a}}$ & $10.0 \pm 0.7^{\mathrm{a}}$ & $13.64 \pm 0.38^{\mathrm{a}}$ \\
& $\mathrm{T}_{2}$ & $12.7 \pm 1.9^{\mathrm{a}}$ & $11.3 \pm 1.6^{\mathrm{a}}$ & $8.2 \pm 0.5^{\mathrm{a}}$ & $13.70 \pm 0.34^{\mathrm{a}}$ \\
\hline
\end{tabular}

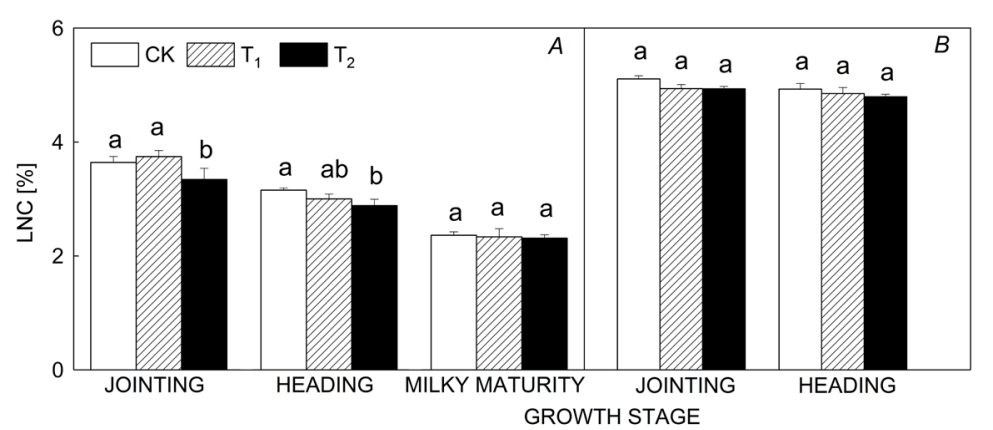

Fig. 2. Effects of different elevated carbon dioxide $\left(\mathrm{eCO}_{2}\right)$ concentrations on leaf nitrogen content (LNC) of rice $(A)$ and winter wheat $(B)$. $\mathrm{CK}$ - ambient $\mathrm{CO}_{2}$

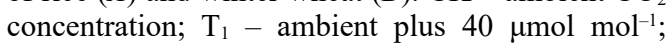

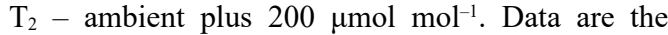
mean values $\pm \mathrm{SE}(n=4)$. Different lowercase letters indicate a significant difference between different treatments at $p<0.05$.

rice (Fig. $2 A$ ). During the winter wheat growing season, the LNC of the $\mathrm{T}_{1}$ and $\mathrm{T}_{2}$ treatments showed a downward trend, although this difference did not reach statistical significance (Fig. 2B).

The relationship between the total photosynthetic rate and the LNC is presented in Fig. 3. During the rice growing season, there was a significant positive correlation between the $P_{\mathrm{g}}$ and LNC. The $R^{2}$ of the CK, $\mathrm{T}_{1}$, and $\mathrm{T}_{2}$ treatments was $0.81,0.67$, and 0.61 , respectively (Fig. $3 A$ ). In contrast, no correlation was found between the $P_{\mathrm{g}}$ and the LNC in winter wheat. The $R^{2}$ of the $\mathrm{CK}, \mathrm{T}_{1}$, and $\mathrm{T}_{2}$ treatments was $0.01,0.38$, and 0.11 , respectively (Fig. $3 B$ ).

Biomass: The effects of different $\mathrm{eCO}_{2}$ concentrations on the biomass of rice and winter wheat are shown in Table 2. During the rice growing season, the $T_{1}$ and $T_{2}$ treatments had no significant effect on the leaf, ear, root, aboveground, or total biomass accumulation. However, the $T_{1}$ and $T_{2}$ treatments generally tended to promote biomass accumulation in all parts of the plants (except for the leaves), and the biomass of the $T_{2}$ treatment was higher than that in the $T_{1}$ treatment. At the jointing stage, compared with the CK treatment, the $\mathrm{T}_{2}$ treatment significantly increased the stem biomass by $49 \%$. During the winter wheat growing season, at the heading stage, compared with the $\mathrm{CK}$ treatment, the $\mathrm{T}_{2}$ treatment significantly increased the leaf, stem, and aboveground biomass by 40,38 , and $40 \%$, respectively.

Yield composition: As shown in Table 3, different $\mathrm{eCO}_{2}$ concentrations had no significant effect on grain number, TGM, and the unfilled grain number of rice. Compared with the $C K$ treatment, the $\mathrm{T}_{2}$ treatment increased the grain number, TWG, and unfilled grain number to some extent, with an increase of $3.3,1.3$, and $22.9 \%$, respectively. For winter wheat, $\mathrm{CO}_{2}$ enrichment tended to increase the number of grains but had no significant effect on the TGM. Compared with the CK treatment, the $\mathrm{T}_{1}$ and $\mathrm{T}_{2}$ treatments increased the grain number by 1.5 and $6.1 \%$, respectively.

Different $\mathrm{eCO}_{2}$ concentrations, in general, could in- 


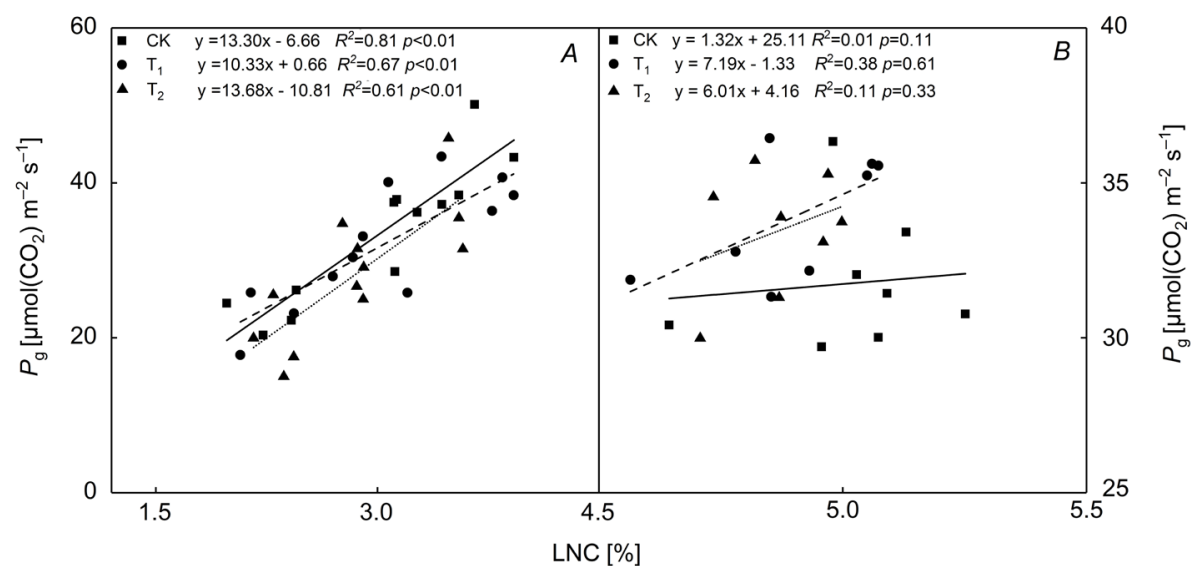

Fig. 3. Relationship between the gross photosynthetic rate $\left(P_{\mathrm{g}}\right)$ and leaf nitrogen content $(\mathrm{LNC})$ of rice $(A)$ and winter wheat $(B)$. CK ambient $\mathrm{CO}_{2}$ concentration; $\mathrm{T}_{1}-$ ambient plus $40 \mu \mathrm{mol} \mathrm{mol} \mathrm{mo}^{-1} ; \mathrm{T}_{2}-$ ambient plus $200 \mu \mathrm{mol} \mathrm{mol}{ }^{-1}$.

Table 2. Effects of different elevated carbon dioxide $\left(\mathrm{eCO}_{2}\right)$ concentrations on the biomass of rice and winter wheat. $\mathrm{CK}-$ ambient $\mathrm{CO}_{2}$

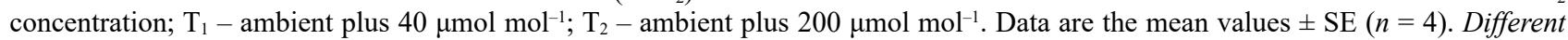
lowercase letters indicate a significant difference between different treatments at $p<0.05$.

\begin{tabular}{llllll}
\hline $\begin{array}{l}\text { Biomass } \\
\text { [g per 5 plants }]\end{array}$ & Treatment & $\begin{array}{l}\text { Rice } \\
\text { Jointing }\end{array}$ & Heading & $\begin{array}{l}\text { Winter wheat } \\
\text { Jointing }\end{array}$ & Heading \\
\hline Leaf & $\mathrm{CK}$ & $11.99 \pm 1.12^{\mathrm{a}}$ & $18.05 \pm 1.43^{\mathrm{a}}$ & $11.55 \pm 2.07^{\mathrm{a}}$ & $11.26 \pm 0.42^{\mathrm{b}}$ \\
& $\mathrm{T}_{1}$ & $12.94 \pm 1.00^{\mathrm{a}}$ & $19.65 \pm 2.00^{\mathrm{a}}$ & $11.88 \pm 0.80^{\mathrm{a}}$ & $12.59 \pm 0.74^{\mathrm{ab}}$ \\
& $\mathrm{T}_{2}$ & $12.31 \pm 1.18^{\mathrm{a}}$ & $16.49 \pm 1.28^{\mathrm{a}}$ & $13.31 \pm 0.73^{\mathrm{a}}$ & $15.75 \pm 2.22^{\mathrm{a}}$ \\
Stem & $\mathrm{CK}$ & $12.43 \pm 1.38^{\mathrm{b}}$ & $32.90 \pm 4.43^{\mathrm{a}}$ & $10.90 \pm 2.65^{\mathrm{a}}$ & $22.71 \pm 1.43^{\mathrm{b}}$ \\
& $\mathrm{T}_{1}$ & $16.46 \pm 2.02^{\mathrm{ab}}$ & $35.89 \pm 4.52^{\mathrm{a}}$ & $11.75 \pm 0.92^{\mathrm{a}}$ & $24.65 \pm 1.79^{\mathrm{ab}}$ \\
& $\mathrm{T}_{2}$ & $18.52 \pm 2.44^{\mathrm{a}}$ & $38.49 \pm 5.36^{\mathrm{a}}$ & $13.58 \pm 1.23^{\mathrm{a}}$ & $31.28 \pm 3.65^{\mathrm{a}}$ \\
Ear & $\mathrm{CK}$ & - & $10.25 \pm 1.15^{\mathrm{a}}$ & - & $2.43 \pm 0.89^{\mathrm{a}}$ \\
& $\mathrm{T}_{1}$ & - & $10.75 \pm 0.86^{\mathrm{a}}$ & - & $3.75 \pm 0.60^{\mathrm{a}}$ \\
& $\mathrm{T}_{2}$ & - & $11.52 \pm 1.07^{\mathrm{a}}$ & - & $3.98 \pm 0.27^{\mathrm{a}}$ \\
Root & $\mathrm{CK}$ & $4.43 \pm 0.39^{\mathrm{a}}$ & $7.47 \pm 1.15^{\mathrm{a}}$ & - & - \\
& $\mathrm{T}_{1}$ & $4.84 \pm 0.01^{\mathrm{a}}$ & $8.52 \pm 1.01^{\mathrm{a}}$ & - & - \\
Aboveground & $\mathrm{T}_{2}$ & $4.87 \pm 0.53^{\mathrm{a}}$ & $10.06 \pm 1.81^{\mathrm{a}}$ & - & - \\
& $\mathrm{CK}^{*}$ & $24.42 \pm 2.50^{\mathrm{a}}$ & $63.39 \pm 7.18^{\mathrm{a}}$ & $22.45 \pm 4.70^{\mathrm{a}}$ & $36.40 \pm 2.07^{\mathrm{b}}$ \\
& $\mathrm{T}_{1}$ & $29.40 \pm 3.02^{\mathrm{a}}$ & $68.26 \pm 7.42^{\mathrm{a}}$ & $23.60 \pm 1.62^{\mathrm{a}}$ & $41.00 \pm 2.65^{\mathrm{ab}}$ \\
Total & $\mathrm{T}_{2}$ & $30.83 \pm 3.62^{\mathrm{a}}$ & $68.54 \pm 7.60^{\mathrm{a}}$ & $26.89 \pm 1.82^{\mathrm{a}}$ & $51.01 \pm 5.71^{\mathrm{a}}$ \\
& $\mathrm{CK}^{*}$ & $28.84 \pm 2.89^{\mathrm{a}}$ & $70.87 \pm 8.29^{\mathrm{a}}$ & - & - \\
& $\mathrm{T}_{1}$ & $34.24 \pm 3.31^{\mathrm{a}}$ & $76.77 \pm 8.26^{\mathrm{a}}$ & - & - \\
\hline & $\mathrm{T}_{2}$ & $35.60 \pm 4.15^{\mathrm{a}}$ & $78.60 \pm 8.95^{\mathrm{a}}$ & - & - \\
\hline
\end{tabular}

Table 3. Effects of different elevated carbon dioxide $\left(\mathrm{eCO}_{2}\right)$ concentrations on yield composition of rice and winter wheat. $\mathrm{CK}-$ ambient $\mathrm{CO}_{2}$ concentration; $\mathrm{T}_{1}$ - ambient plus $40 \mu \mathrm{mol} \mathrm{mol}^{-1} ; \mathrm{T}_{2}$ - ambient plus $200 \mu \mathrm{mol} \mathrm{mol}^{-1} ; \mathrm{TGM}$ - thousand-grain mass. Data are the mean values $\pm \operatorname{SE}(n=4)$. Different lowercase letters indicate a significant difference between different treatments at $p<0.05$.

\begin{tabular}{llllll}
\hline Treatment & \multicolumn{2}{c}{ Rice [15 plants] } & & \multicolumn{2}{c}{ Winter wheat [20 plants] } \\
& Grain number & TGM [g] & Unfilled grain number & Grain number & TGM [g] \\
\hline $\mathrm{CK}$ & $2,902 \pm 61^{\mathrm{a}}$ & $21.72 \pm 0.30^{\mathrm{a}}$ & $310 \pm 32^{\mathrm{a}}$ & $962 \pm 43^{\mathrm{a}}$ & $40.07 \pm 0.37^{\mathrm{a}}$ \\
$\mathrm{T}_{1}$ & $2,845 \pm 57^{\mathrm{a}}$ & $21.76 \pm 0.19^{\mathrm{a}}$ & $305 \pm 36^{\mathrm{a}}$ & $976 \pm 53^{\mathrm{a}}$ & $40.16 \pm 0.31^{\mathrm{a}}$ \\
$\mathrm{T}_{2}$ & $2,997 \pm 87^{\mathrm{a}}$ & $22.00 \pm 0.19^{\mathrm{a}}$ & $381 \pm 27^{\mathrm{a}}$ & $1,021 \pm 35^{\mathrm{a}}$ & $40.12 \pm 0.24^{\mathrm{a}}$ \\
\hline
\end{tabular}

crease the yield of rice and winter wheat to a certain extent (Fig. 4). For rice, the $\mathrm{T}_{1}$ and $\mathrm{T}_{2}$ treatments tended to increase the yield, although this difference did not reach statistical significance (Fig. 4A). Compared with the CK treatment, the $T_{1}$ and $T_{2}$ treatments increased the yield of rice by $37.37 \mathrm{~g} \mathrm{~m}^{-2}$ and $167.10 \mathrm{~g} \mathrm{~m}^{-2}$, with an increase of 3.0 and $13.5 \%$, respectively. Compared with the $T_{1}$ treatment, the $T_{2}$ treatment increased yield by 


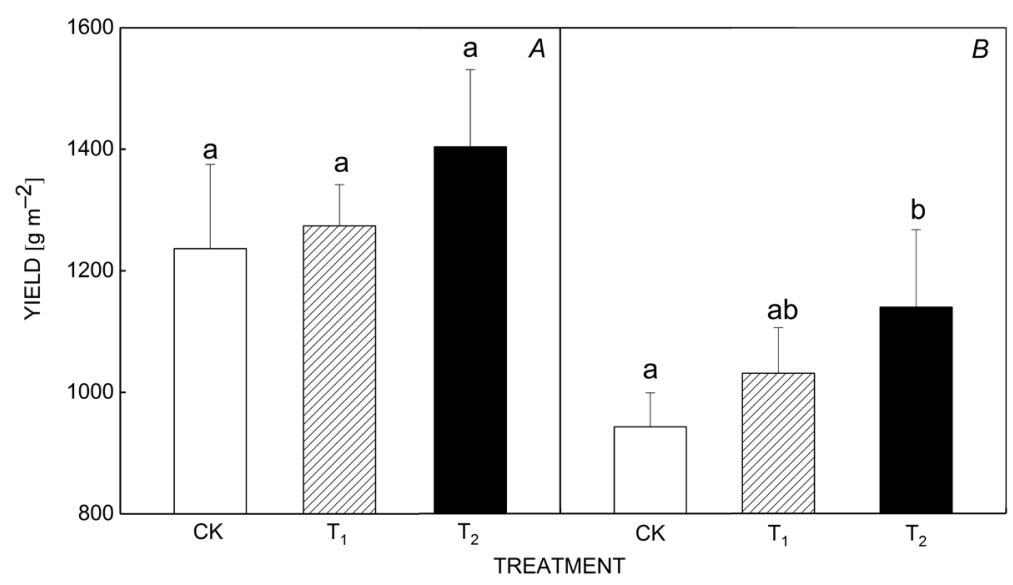

Fig. 4. Effects of different elevated carbon dioxide $\left(\mathrm{eCO}_{2}\right)$ concentrations on the yield of rice $(A)$ and winter wheat $(B)$. $\mathrm{CK}-$ ambient $\mathrm{CO}_{2}$ concentration; $\mathrm{T}_{1}-$ ambient plus $40 \mu \mathrm{mol} \mathrm{mol}^{-1}$; $\mathrm{T}_{2}$ - ambient plus $200 \mu \mathrm{mol} \mathrm{mol}{ }^{-1}$. Data are the mean values $\pm \operatorname{SE}(n=4)$. Different lowercase letters indicate a significant difference between different treatments at $p<0.05$.
$129.73 \mathrm{~g} \mathrm{~m}^{-2}$, with an increase of $10.2 \%$. It can be seen from Fig $4 B$, compared with the $\mathrm{CK}$ and $\mathrm{T}_{1}$ treatments, that the $\mathrm{T}_{2}$ treatment increased the yield of winter wheat by $196.75 \mathrm{~g} \mathrm{~m}^{-2}$ and $108.82 \mathrm{~g} \mathrm{~m}^{-2}$, with an increase of 20.9 and $10.6 \%$; the $\mathrm{T}_{1}$ treatment increased the yield by $87.93 \mathrm{~g} \mathrm{~m}^{-2}$, with an increase of $9.3 \%$.

\section{Discussion}

Photosynthesis provides energy for biomass accumulation and is one of the important factors for plant growth and development (Lu et al. 2017). It has been well documented that short-term (a period of min to hours) $\mathrm{eCO}_{2}$ concentrations stimulate photosynthesis, while the initial stimulation of photosynthesis gradually decreases after long-term (a period of weeks to months) $\mathrm{eCO}_{2}$ concentration exposure (Bloom et al. 2002, Seneweera et al. 2011). In this study, the photosynthetic characteristics showed different trends of rice and winter wheat in response to $\mathrm{eCO}_{2}$ concentrations. In rice, we observed that the $T_{2}$ treatment significantly decreased the photosynthetic capacity of leaves compared to the $\mathrm{CK}$ and $\mathrm{T}_{1}$ treatments (Fig. 1A). This demonstrates that the rice appeared to have undergone photosynthetic downregulation to the high $\mathrm{eCO}_{2}$ concentrations. The reasons for the photosynthetic downregulation mainly include stomatal limitation and nonstomatal factors (Farquhar and Sharkey 1982). In our study, although the $g_{\mathrm{s}}$ under the $\mathrm{T}_{2}$ treatment showed a downward trend (Fig. $1 C$ ), the $C_{\mathrm{i}}$ values among different treatments were similar during the rice growing season (Fig. 1E). Besides, no significant difference in $C_{\mathrm{i}} / C_{\mathrm{a}}$ was found under different treatments (Fig. $1 G$ ). Therefore, in our study, this eliminates the phenomenon of photosynthetic acclimation due to reduced stomatal limitation (Chen et al. 2005). Rubisco enzyme plays an important role in the photosynthesis of plants (Vicente et al. 2015), accounting for 15-35\% of total $\mathrm{LNC}$ in $\mathrm{C}_{3}$ plants (Evans 1989, Makino and Osmond 1991). Some studies have reported that the decreased amount and activity of Rubisco may be related to a decrease in LNC (Aranjuelo et al. 2011, Wang et al. 2013). In our study, a significant decrease in LNC was observed under the $\mathrm{T}_{2}$ treatment in rice (Fig. $2 A$ ), which might partly explain why the photosynthetic acclimation appeared under the high $\mathrm{CO}_{2}$ concentration. It is noteworthy that, although rice and wheat are $\mathrm{C}_{3}$ plants, our study found that there was no significant effect on $P_{\mathrm{N}}$ under different treatments, and high $\mathrm{CO}_{2}$ concentration did not lead to photosynthesis downregulation phenomenon during the winter wheat growing season (Fig. 1B). The possible reason is that, on the one hand, the photosynthesis of plants will have different responses due to different species, and even the same plant will have different responses to $\mathrm{CO}_{2}$ at different growth and development stages. Also, the differences in photosynthetic characteristics are usually detected, and a significant intraspecific variation in responses to $\mathrm{eCO}_{2}$ has been found in rice and wheat (Woodrow 1994). On the other hand, wheat grown under the high $\mathrm{CO}_{2}$ enrichment environment only showed a decrease in photosynthetic capacity when the nitrogen supply is low, and no photosynthesis downregulation occurred under appropriate fertilization conditions (Gutiérrez et al. 2013).

Photosynthesis characteristic parameters reflect the ability of plants to benefit from light energy and $\mathrm{CO}_{2}$ and can be used to evaluate photosynthetic physiological and ecological characteristics of plants (Pan et al. 2020). The $P_{\mathrm{Nmax}}$ is the key index to measure the maximum photosynthetic capacity of leaves. As can be seen from Table 1, the T2 treatment significantly increased the $P_{\mathrm{Nmax}}$ of rice. However, although the $P_{\mathrm{Nmax}}$ of winter wheat showed an increasing trend under $\mathrm{eCO}_{2}$ conditions, it did not reach statistical significance. The results indicated that high $\mathrm{CO}_{2}$ enrichment could improve the maximum photosynthetic capacity of rice and winter wheat to some extent. The values of AQY and $\mathrm{CE}$ are the initial slopes of lightresponse and $\mathrm{CO}_{2}$-response curves, respectively, which can reflect the ability of plants to utilize low light energy and low $\mathrm{CO}_{2}$ concentration. In our study, AQY increased with the rising $\mathrm{CO}_{2}$ concentrations, although this difference did not reach statistical significance. The results showed that $\mathrm{CO}_{2}$ enrichment is beneficial to improve AQY, which may increase the $P_{\mathrm{Nmax}}$ of rice and winter wheat. During the rice growing season, the $\mathrm{CE}$ was marginally reduced under the $\mathrm{T}_{2}$ treatment, which may be related to the decrease of LNC due to high $\mathrm{CO}_{2}$ concentration. This indicates that high $\mathrm{CO}_{2}$ concentration further reduces the utilization ability of rice at low concentrations of $\mathrm{CO}_{2}$. Besides, we also found that, compared with high $\mathrm{CO}_{2}$ concentration, 
low $\mathrm{eCO}_{2}$ concentration did not affect the photosynthetic characteristics, such as $P_{\mathrm{N}}, g_{\mathrm{s}}, C_{\mathrm{i}}, C_{\mathrm{i}} / C_{\mathrm{a}}, P_{\mathrm{N} \max }, R_{\mathrm{D}}, \mathrm{CE}$, and $R_{\mathrm{p}}$, during the whole rice and winter wheat growing seasons (Fig. 1, Table 1). The possible reason is that, in our experiment, the set low $\mathrm{eCO}_{2}$ concentration (ambient plus $40 \mu \mathrm{mol} \mathrm{mol}{ }^{-1}$ ) is closer to the natural environment, and the influence of $\mathrm{CO}_{2}$ concentration on plants' physiology and ecology may not be as obvious as that of high $\mathrm{eCO}_{2}$

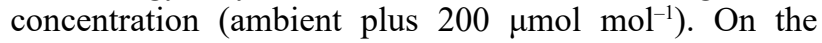
other hand, due to the adaptability of plants, the low $\mathrm{eCO}_{2}$ concentration is close to the plant's natural growth environment, it may adapt to the increase of lower $\mathrm{CO}_{2}$ concentration in a short time. Therefore, photosynthetic characteristics of low eCO $\mathrm{eC}_{2}$ concentrations are close to the control treatment.

The growth of plants at atmospheric $\mathrm{CO}_{2}$ concentrations greater than the ambient levels could greatly influence plant tissue chemistry (Loladze 2002, Taub and Wang 2008). Nitrogen is an important component of plant synthesis of chlorophyll and various enzymes, and approximately $75 \%$ of the nitrogen in plant leaves occurs in chloroplasts, most of which are used to construct photosynthetic apparatus (Takashima et al. 2004). It has been reported that the long-term response to $\mathrm{CO}_{2}$ concentrations is mainly due to the limitation of nitrogen supply (Seneweera 2011). Many experiments have also detected a decrease in plant tissue nitrogen concentration under $\mathrm{CO}_{2}$ enrichment conditions (Ainsworth and Long 2005, Norby et al. 2010), particularly in leaf tissues (Seneweera 2011). For example, Xie et al. (2002) found that the LNC of rice decreased by $8.4,9.7,10.2$, and $3.2 \%$ at the tillering, jointing, heading, and maturity stages, respectively, under the FACE experiment. In the FACE study in Arizona, it was found that under severe $\mathrm{N}$ deficiency, the increase of $\mathrm{CO}_{2}$ concentration reduced the LNC by $25 \%$ in the first year and by $19 \%$ in the second year on average, but the LNC of wheat was not affected under optimum conditions in a 4-year FACE experiment (Sinclair et al. 2000). In our present study, high $\mathrm{CO}_{2}$ concentration significantly reduced LNC of rice (Fig. $2 A$ ), and the LNC of winter wheat was slightly but insignificantly reduced under different $\mathrm{eCO}_{2}$ concentrations (Fig. 2B). This is consistent with the previous research results. Moreover, the low $\mathrm{eCO}_{2}$ concentration had no significant effect on the $\mathrm{LNC}$ of rice and winter wheat. It has been predicted that increased photoassimilate accumulation in plants as a result of $\mathrm{eCO}_{2}$ concentrations will result in a dilution of plant $\mathrm{N}$ such that the $\mathrm{N}$ concentration in the leaves will decrease (Gifford et al. 2000). As shown by our results, in general, the different $\mathrm{CO}_{2}$ treatments stimulated the biomass accumulation and diluted $\mathrm{N}$ content in plant tissues to a certain extent (Table 2), which may account for the decrease in LNC. Studies have shown that there is a strong and significant positive correlation between photosynthetic capacity and LNC (Zhang et al. 2010). Some studies, however, have indicated that photosynthetic capacity is either negatively or insignificantly correlated with LNC among species (Takashima et al. 2004). In the present study, we found that there was a significant positive correlation between the $P_{\mathrm{g}}$ and $\mathrm{LNC}$ during the rice growing season
(Fig. 3A), while no correlation was found during the winter wheat growing season (Fig. $3 B$ ). This may be due to the differences in $\mathrm{N}$ partitioning between thylakoid and soluble proteins, electron transport capacity, and specific activities of Rubisco, which caused that the relationship between LNC and photosynthetic capacity varied among different plants (Evans 1989). The ratio of photosynthetic capacity to LNC can be used as an indicator to evaluate the photosynthetic efficiency of nitrogen input, which is PNUE, which can be used to express the instantaneous measure of the relationship between nitrogen-use efficiency and fixed $\mathrm{CO}_{2}$ (Takashima et al. 2004). As shown in Fig. $3 \mathrm{~A}$, different $\mathrm{eCO}_{2}$ concentrations did not affect the PNUE, demonstrating that the increase of $\mathrm{CO}_{2}$ concentrations did not affect the physiological utilization rate of nitrogen in rice leaves. In contrast, there was no correlation in winter wheat; it may be that each species has a different $\mathrm{N}$ allocation to various components, which leads to the difference of photosynthesis-N relationship and PNUE between different species (Pierce et al. 2003, Novriyanti et al. 2012).

The concentration of $\mathrm{eCO}_{2}$ affects plant photosynthesis, which in turn may impact the potential growth and development of roots, stems, leaves, and other organs (Srivastava et al. 2001). Biomass increases in rice and winter wheat under $\mathrm{eCO}_{2}$ concentrations have been widely reported (Dijkstra et al. 1999, Kim et al. 2003, Yang et al. 2006). Here, we assessed the effects of different $\mathrm{eCO}_{2}$ concentrations on the biomass of rice and winter wheat. No significant change in biomass was found during the rice growing stages (Table 2). We did, however, observed that high $\mathrm{CO}_{2}$ concentration significantly increased the biomass of leaf, stem, and aboveground mass at the heading stage in winter wheat. Furthermore, we also found the biomass accumulation was greater in the $\mathrm{T}_{2}$ treatment as compared to the $\mathrm{T}_{1}$ treatment. This suggested that plants have higher photosynthetic capacity under high $\mathrm{CO}_{2}$ conditions, which inevitably promoted fixation and transformation of carbon, thus increasing the accumulation of more biomass. As can be seen from Table 1 , in general, the $P_{\mathrm{Nmax}}$ of the $\mathrm{T}_{2}$ treatment was greater than that grown under the $\mathrm{CK}$ and $\mathrm{T}_{1}$ treatments, which may be beneficial to promote the biomass accumulation of rice and wheat to a certain extent.

Material production and accumulation are the basis of crop yield formation. Using meta-analysis techniques, it was indicated that the average crop yield increased by $17 \%$ under $\mathrm{eCO}_{2}$ conditions (Ainsworth and Long 2005), among which the yield of rice and wheat increased by 20\% (Wang et al. 2015) and 24\% (Wang et al. 2013), respectively. In this study, we found that the yield of rice and winter wheat increased with the rising $\mathrm{CO}_{2}$ concentrations to some extent (Fig. 4), and high $\mathrm{eCO}_{2}$ concentration significantly increased the yield of winter wheat (Fig. 4B). The results are in agreement with former studies, although the magnitude of increase varies depending upon location and cultivar. Furthermore, in general, the $\mathrm{T}_{2}$ treatment showed a higher yield of rice and winter wheat than those grown in the $T_{1}$ treatment. This is probably because high $\mathrm{CO}_{2}$ concentrations promoted a greater increase in grain number and TGM of rice and 
winter wheat (Table 3). According to regression analysis, the fitting equations of rice and winter wheat yield and different $\mathrm{eCO}_{2}$ concentrations were: $y=0.83 x+906.9$ $\left(R^{2}=0.99\right)$ and $y=0.90 x+607.1\left(R^{2}=0.97\right)$, respectively, which indicated that there was a positive correlation between the yield of rice and winter wheat and $\mathrm{CO}_{2}$ concentration within a certain range. Similar results have been reported by Long et al. (2006), using a meta-analysis of crop yield response to the $\mathrm{CO}_{2}$ enrichment, showing that crop yield responded linearly to the increase of $\mathrm{CO}_{2}$ concentrations.

Conclusions: In summary, our results showed that photosynthetic acclimation was observed under high $\mathrm{eCO}_{2}$ concentration. Besides, the high $\mathrm{eCO}_{2}$ concentration significantly increased $P_{\mathrm{Nmax}}$ but decreased the LNC during the rice growing season. Moreover, high $\mathrm{eCO}_{2}$ concentration promoted higher biomass accumulation and yield than the low $\mathrm{eCO}_{2}$ concentration in rice and winter wheat. In contrast, the low $\mathrm{eCO}_{2}$ concentration had little effect on photosynthetic characteristics, LNC, biomass accumulation, and yield during the rice and winter wheat growing seasons. This study, therefore, indicated that the photosynthesis and growth of rice and winter wheat have different responses to high and low $\mathrm{eCO}_{2}$ concentrations. As the low $\mathrm{eCO}_{2}$ concentrations are closer to the natural growth environment of plants, in general, the photosynthetic performance and growth of plants, especially for $\mathrm{C}_{3}$ plants, are relatively insensitive to low $\mathrm{eCO}_{2}$ concentrations compared to high $\mathrm{eCO}_{2}$ concentrations. It is noteworthy that atmospheric $\mathrm{CO}_{2}$ concentrations change gradually, and our experiment was only conducted for one year. It is not clear whether plants grown under low $\mathrm{eCO}_{2}$ concentrations have a 'memory effect', and therefore the effects of gradually increasing $\mathrm{CO}_{2}$ concentrations on the progeny of the rice and winter wheat should be further studied.

\section{References}

Ainsworth E.A., Long S.P.: What have we learned from 15 years of free-air $\mathrm{CO}_{2}$ enrichment (FACE)? A meta-analytic review of the responses of photosynthesis, canopy properties and plant production to rising $\mathrm{CO}_{2}$. - New Phytol. 165: 351-372, 2005.

Ainsworth E.A., Rogers A.: The response of photosynthesis and stomatal conductance to rising $\left[\mathrm{CO}_{2}\right]$ : mechanisms and environmental interactions. - Plant Cell Environ. 30: 258270, 2007.

Alonso A., Pérez P., Martínez-Carrasco R. et al.: Growth in elevated $\mathrm{CO}_{2}$ enhances temperature response of photosynthesis in wheat. - Physiol. Plantarum 135: 109-120, 2009.

Aranjuelo I., Cabrera-Bosquet L., Morcuende R. et al:: Does ear $\mathrm{C}$ sink strength contribute to overcoming photosynthetic acclimation of wheat plants exposed to elevated $\mathrm{CO}_{2}$ ? J. Exp. Bot. 62: 3957-3969, 2011.

Bencke-Malato M., De Souza A.P., Ribeiro-Alves M. et al.: Short-term responses of soybean roots to individual and combinatorial effects of elevated $\left[\mathrm{CO}_{2}\right]$ and water deficit. Plant Sci. 280: 283-296, 2019.

Bishop K.A., Leakey A.D. Ainsworth E.A.: How seasonal temperature or water inputs affect the relative response of $\mathrm{C}_{3}$ crops to elevated $\left[\mathrm{CO}_{2}\right]$ : a global analysis of open top chamber and free air $\mathrm{CO}_{2}$ enrichment studies. - Food Energ. Secur. 3: 33-45, 2014.

Bloom A.J., Smart D.R., Nguyen D.T., Searles P.S.: Nitrogen assimilation and growth of wheat under elevated carbon dioxide. - P. Natl. Acad. Sci. USA 99: 1730-1735, 2002.

Chen G.Y., Yong Z.H., Liao Y. et al.: Photosynthetic acclimation in rice leaves to free-air $\mathrm{CO}_{2}$ enrichment related to both ribulose-1,5-bisphosphate carboxylation limitation and ribulose-1,5-bisphosphate regeneration limitation. - Plant Cell Physiol. 46: 1036-1045, 2005.

Dier M., Sickora J., Erbs M. et al.: Positive effects of free air $\mathrm{CO}_{2}$ enrichment on $\mathrm{N}$ remobilization and post-anthesis $\mathrm{N}$ uptake in winter wheat. - Field Crop. Res. 234: 107-118, 2019.

Dijkstra P., Schapendonk A.H., Groenwold K. et al.: Seasonal changes in the response of winter wheat to elevated atmospheric $\mathrm{CO}_{2}$ concentration grown in open-top chambers and field tracking enclosures. - Glob. Change Biol. 5: 563576, 1999.

Dusenge M.E., Duarte A.G., Way D.A.: Plant carbon metabolism and climate change: elevated $\mathrm{CO}_{2}$ and temperature impacts on photosynthesis, photorespiration and respiration. - New Phytol. 221: 32-49, 2019.

Evans J.R.: Photosynthesis and nitrogen relationships in leaves of $\mathrm{C}_{3}$ plants. - Oecologia 78: 9-19, 1989.

Farquhar G.D., Sharkey T.D.: Stomatal conductance and photosynthesis. - Ann. Rev. Plant Physio. 33: 317-345, 1982.

Gifford R.M., Barrett D.J., Lutze J.L.: The effects of elevated $\left[\mathrm{CO}_{2}\right]$ on the $\mathrm{C}: \mathrm{N}$ and $\mathrm{C}: \mathrm{P}$ mass ratios of plant tissues. - Plant Soil 224: 1-14, 2000.

Guo L.J., Lin S., Liu T.Q. et al.: Effects of conservation tillage on topsoil microbial metabolic characteristics and organic carbon within aggregates under a rice (Oryza sativa L.)-wheat (Triticum aestivum L.) cropping system in central China. PLoS One 11: e0146145, 2016.

Gutiérrez D., Morcuende R., Del Pozo A. et al.: Involvement of nitrogen and cytokinins in photosynthetic acclimation to elevated $\mathrm{CO}_{2}$ of spring wheat. - J. Plant Physiol. 170: 1337$1343,2013$.

IPCC 2014: Climate Change 2014: Synthesis Report. Contribution of Working Groups I, II and III to the Fifth Assessment Report of the Intergovernmental Panel on Climate Change. Pp. 151. IPCC, Geneva 2014.

Kim H.Y., Lieffering M., Kobayashi K. et al.: Seasonal changes in the effects of elevated $\mathrm{CO}_{2}$ on rice at three levels of nitrogen supply: a free air $\mathrm{CO}_{2}$ enrichment (FACE) experiment. - Glob. Change Biol. 9: 826-837, 2003.

Kimball B.A.: Crop responses to elevated $\mathrm{CO}_{2}$ and interactions with $\mathrm{H}_{2} \mathrm{O}, \mathrm{N}$, and temperature. - Curr. Opin. Plant Biol. 31: 36-43, 2016

Leakey A.D.B., Ainsworth E.A., Bernacchi C.J. et al.: Elevated $\mathrm{CO}_{2}$ effects on plant carbon, nitrogen, and water relations: six important lessons from FACE. - J. Exp. Bot. 60: 2859-2876, 2009.

Liu H.J., Yang L.X., Wang Y.L. et al.: Yield formation of $\mathrm{CO}_{2}$-enriched hybrid rice cultivar Shanyou 63 under fully open-air field conditions. - Field Crop. Res. 108: 93-100, 2008.

Loladze I.: Rising atmospheric $\mathrm{CO}_{2}$ and human nutrition: toward globally imbalanced plant stoichiometry? - Trends Ecol. Evol. 17: 457-461, 2002.

Long S.P., Ainsworth E.A., Leakey A.D.B. et al.: Food for thought: Lower-than-expected crop yield stimulation with rising $\mathrm{CO}_{2}$ concentrations. - Science 312: 1918-1921, 2006.

$\mathrm{Lu}$ T., Meng Z.J., Zhang G.X. et al.: Sub-high temperature and high light intensity induced irreversible inhibition on 
photosynthesis system of tomato plant (Solanum lycopersicum L.). - Front. Plant Sci. 8: 365, 2017.

Lv C.H., Huang Y., Sun W.J. et al.: Response of rice yield and yield components to elevated $\left[\mathrm{CO}_{2}\right]$ : a synthesis of updated data from FACE experiments. - Eur. J. Agron. 112: 125961, 2020.

Makino A., Osmond B.: Effects of nitrogen nutrition on nitrogen partitioning between chloroplasts and mitochondria in pea and wheat. - Plant Physiol. 96: 355-362, 1991.

Moon M., Kang K.S., Park I.K. et al.: Effects of leaf nitrogen allocation on the photosynthetic nitrogen-use efficiency of seedlings of three tropical species in Indonesia. - J. Korean Soc. Appl. Bi. 58: 511-519, 2015.

Norby R.J., Warren J.M., Iversen C.M. et al.: $\mathrm{CO}_{2}$ enhancement of forest productivity constrained by limited nitrogen availability. - P. Natl. Acad. Sci. USA 107: 19368-19373, 2010.

Novriyanti E., Watanabe M., Makoto K. et al.: Photosynthetic nitrogen- and water-use efficiency of acacia and eucalypt seedlings as afforestation species. - Photosynthetica 50: 273-281, 2012.

Nowak R.S., Ellsworth D.S., Smith S.D.: Functional responses of plants to elevated atmospheric $\mathrm{CO}_{2}$ : Do photosynthetic and productivity data from FACE experiments support early predictions? - New Phytol. 162: 253-280, 2004.

Pan T.H., Wang Y.L., Wang L.H. et al.: Increased $\mathrm{CO}_{2}$ and light intensity regulate growth and leaf gas exchange in tomato. Physiol. Plantarum 168: 694-708, 2020.

Pastore M.A., Lee T.D., Hobbie S.E., Reich P.B.: Strong photosynthetic acclimation and enhanced water-use efficiency in grassland functional groups persist over 21 years of $\mathrm{CO}_{2}$ enrichment, independent of nitrogen supply. - Glob. Change Biol. 25: 3031-3044, 2019.

Pierce S., Stirling C.M., Baxter R.: Pseudoviviparous reproduction of Poa alpina var. vivipara L. (Poaceae) during long-term exposure to elevated atmospheric $\mathrm{CO}_{2}$. - Ann. Bot.London 91: 613-622, 2003.

Reddy A.R., Rasineni G.K., Raghavendra A.S.: The impact of global elevated $\mathrm{CO}_{2}$ concentration on photosynthesis and plant productivity. - Curr. Sci. India 99: 46-57, 2010.

Saha S., Chakraborty D., Sehgal V.K., Pal M.: Rising atmospheric $\mathrm{CO}_{2}$ : Potential impacts on chickpea seed quality. - Agr. Ecosyst. Environ. 203: 140-146, 2015.

Salazar-Parra C., Aranjuelo I., Pascual I. et al.: Carbon balance, partitioning and photosynthetic acclimation in fruit-bearing grapevine (Vitis vinifera L. cv. Tempranillo) grown under simulated climate change (elevated $\mathrm{CO}_{2}$, elevated temperature and moderate drought) scenarios in temperature gradient greenhouses. - J. Plant Physiol. 174: 97-109, 2015.

Seneweera S.: Effects of elevated $\mathrm{CO}_{2}$ on plant growth and nutrient partitioning of rice (Oryza sativa L.) at rapid tillering and physiological maturity. - J. Plant Interact. 6: 35-42, 2011.

Seneweera S., Ghannoum O., Ishimaru K. et al:: Changes in source-sink relations during development influence photosynthetic acclimation of rice to free air $\mathrm{CO}_{2}$ enrichment (FACE). - Funct. Plant Biol. 29: 947-955, 2002.

Seneweera S., Makino A., Hirotsu N. et al.: New insight into photosynthetic acclimation to elevated $\mathrm{CO}_{2}$ : The role of leaf nitrogen and ribulose-1,5-bisphosphate carboxylase/ oxygenase content in rice leaves. - Environ. Exp. Bot. 71: 128-136, 2011.

Shabbir A., Dhileepan K., Zalucki M.P., Adkins S.W.: Biological control under a changing climate: The efficacy of the parthenium weed stem-galling moth under an atmosphere enriched with $\mathrm{CO}_{2}$. - Biol. Control 139: 104077, 2019.

Sinclair T.R., Pinter P.J., Kimball B.A. et al.: Leaf nitrogen concentration of wheat subjected to elevated $\left[\mathrm{CO}_{2}\right]$ and either water or N deficits. - Agr. Ecosyst. Environ. 79: 53-60, 2000.

Singh S.K., Reddy V.R., Fleisher D.H., Timlin D.J.: Relationship between photosynthetic pigments and chlorophyll fluorescence in soybean under varying phosphorus nutrition at ambient and elevated $\mathrm{CO}_{2}$. - Photosynthetica 55: 421-433, 2017.

Srinivasarao C., Kundu S., Shanker A.K. et al.: Continuous cropping under elevated $\mathrm{CO}_{2}$ : Differential effects on $\mathrm{C}_{4}$ and $\mathrm{C}_{3}$ crops, soil properties and carbon dynamics in semi-arid alfisols. - Agr. Ecosyst. Environ. 218: 73-86, 2016.

Srivastava A., Pal M., Das M.: Growth, $\mathrm{CO}_{2}$ exchange rate and dry matter partitioning in mungbean (Vigna radiata L.) grown under elevated $\mathrm{CO}_{2}$. - Indian J. Exp. Biol. 39: 572-577, 2001.

Takashima T., Hikosaka K., Hirose T.: Photosynthesis or persistence: nitrogen allocation in leaves of evergreen and deciduous Quercus species. - Plant Cell Environ. 27: 10471054, 2004.

Taub D.R., Wang X.: Why are nitrogen concentrations in plant tissues lower under elevated $\mathrm{CO}_{2}$ ? A critical examination of the hypotheses. - J. Integr. Plant Biol. 50: 1365-1374, 2008.

Tausz M., Tausz-Posch S., Norton R.M. et al.: Understanding crop physiology to select breeding targets and improve crop management under increasing atmospheric $\mathrm{CO}_{2}$ concentrations. - Environ. Exp. Bot. 88: 71-80, 2013.

Tausz-Posch S., Tausz M., Bourgault M.: Elevated $\left[\mathrm{CO}_{2}\right]$ effects on crops: Advances in understanding acclimation, nitrogen dynamics and interactions with drought and other organisms. Plant Biol. 22: 38-51, 2020.

Thornley J.H.: Mathematical Models in Plant Physiology. Pp. 318. Academic Press, London 1976.

Tilman D., Baizer C., Hill J., Befort B.L.: Global food demand and the sustainable intensification of agriculture. - P. Natl. Acad. Sci. USA 108: 20260-20264, 2011.

Uprety D.C., Garg S.C., Bisht B.S. et al.: Carbon dioxide enrichment technologies for crop response studies. - J. Sci. Ind. Res. India 65: 859-866, 2006.

Vicente R., Pérez P., Martínez-Carrasco R. et al.: Quantitative RT-PCR platform to measure transcript levels of C and N metabolism-related genes in durum wheat: Transcript profiles in elevated $\left[\mathrm{CO}_{2}\right]$ and high temperature at different levels of $\mathrm{N}$ supply. - Plant Cell Physiol. 56: 1556-1573, 2015.

Wang J.Y., Wang C., Chen N.N. et al.: Response of rice production to elevated $\left[\mathrm{CO}_{2}\right]$ and its interaction with rising temperature or nitrogen supply: A meta-analysis. - Climatic Change 130: 529-543, 2015.

Wang L., Feng Z.Z., Schjoerring J.K.: Effects of elevated atmospheric $\mathrm{CO}_{2}$ on physiology and yield of wheat (Triticum aestivum L.): A meta-analytic test of current hypotheses. Agr. Ecosyst. Environ. 178: 57-63, 2013.

Warren J.M., Jensen A.M., Medlyn B.E. et al.: Carbon dioxide stimulation of photosynthesis in Liquidambar styraciflua is not sustained during a 12-year field experiment. - AoB Plants 7: plu074, 2015.

Watling J.R., Press M.C., Quick W.P.: Elevated $\mathrm{CO}_{2}$ induces biochemical and ultrastructural changes in leaves of the $\mathrm{C}_{4}$ cereal sorghum. - Plant Physiol. 123: 1143-1152, 2000.

Woodrow I.E.: Optimal acclimation of the $\mathrm{C}_{3}$ photosynthetic system under enhanced $\mathrm{CO}_{2}$. - Photosynth. Res. 39: 401-412, 1994.

Xie Z.B., Zhu J.G., Zhang Y.L. et al.: [Responses of rice (Oryza sativa) growth and its $\mathrm{C}, \mathrm{N}$ and $\mathrm{P}$ composition to FACE (Freeair Carbon Dioxide Enrichment) and N, P fertilization.] Chin. J. Appl. Ecol. 13: 1223-1230, 2002. [In Chinese] doi: 10.3321/j.issn:1001-9332.2002.10.006.

Yang L.X., Huang J.Y., Yang H.J. et al.: Seasonal changes in the effects of free-air $\mathrm{CO}_{2}$ enrichment (FACE) on dry matter 
production and distribution of rice (Oryza sativa L.). - Field Crop. Res. 98: 12-19, 2006.

Yong Z.H., Chen G.Y., Zhang D.Y. et al.: Is photosynthetic acclimation to free-air $\mathrm{CO}_{2}$ enrichment (FACE) related to a strong competition for the assimilatory power between carbon assimilation and nitrogen assimilation in rice leaf? Photosynthetica 45: 85-91, 2007.
Zhang X.C., Yu X.F., Gao S.M.: [Effects of nitrogen application rates on photosynthetic energy utilization in wheat leaves under elevated atmospheric $\mathrm{CO}_{2}$ concentration.] - J. Plant Ecol. 34: 1196-1203, 2010. [In Chinese] doi: 10.3773/ j.issn.1005-264x.2010.10.008.

(C) The authors. This is an open access article distributed under the terms of the Creative Commons BY-NC-ND Licence. 